\title{
PELAKSANAAN DAN PENGUNGKAPAN GOOD CORPORATE GOVERNANCE PADA BANK UMUM SYARIAH
}

\author{
Resti Ardhanareswari \\ Fakultas Ekonomi dan Bisnis Magister Akuntansi Universitas Padjadjaran \\ Email: resti2607@gmail.com
}

\begin{abstract}
Abstrak
$\mathrm{P}$ rinsip GCG yaitu transparansi, akuntabilitas, responsibilitas, independensi serta kewajaran dan kesetaraan diperlukan unuk mencapai kesinambungan usaha (sustainability) perusahaan dengan memperhatikan pemangku kepentingan (stakeholders). Sama halnya dengan pelaksanaan Good Corporate Governance, pengungkapan Good Corporate Governance Bank Umum Syariah ini mengacu pada Peraturan Bank Indonesia Nomor 11/33/PBI/2009 yang masih digunakan hingga saat ini oleh Bank Umum Syariah sesuai Laporan dan Penilaian Pelaksanaan GCG Paragraf 1 Laporan Pelaksanaan GCG Pasal 62. Metode penelitian yang digunakan adalah penelitian kualitatif yang secara deskriptif lebih menekankan pada perkiraan daripada pengukuran. Penulis memilih studi deskriptif karena penyediaan informasi yang dibutuhkan berupa referensireferensi terkait dan data yang diambil berupa laporan tata kelola perusahaan (Good Corporate Governance) periode 2015. Populasi yang diambil adalah Bank Umum Syariah milik BUMN. Sampel yang digunakan adalah BNI Syariah dan BRI Syariah. Dilihat dari hasil pelaksanaan dan pengungkapan Good Corporate Governance khususnya pada kedua Bank Umum Syariah yaitu BNI Syariah dan BRISyariah maka pelaksanaan Good Corporate Governance kedepannya harus berjalan lebih efektif dan tentunya memiliki score/rating GCG yang tinggi. Selain itu, pelaksanaan dan pengungkapan Good Corporate Governance harus sesuai sesuai dengan prinsip-prinsip Good Corporate Governance itu sendiri yaitu transparansi, akuntabilitas, responsibilitas, independensi serta kewajaran dan kesetaraan.
\end{abstract}

Kata kunci: Pelaksanaan dan Pengungkapan Good Corporate Governance

Abstract
CG principles of transparency, accountability, responsibility,
independence and fairness required under on achieving sustainability
(sustainability) Companies with regard stakeholders (stakeholders).
As with the implementation of good corporate governance, disclosure of Good
Corporate Governance Islamic Banks is referring to Bank Indonesia Regulation
Number $11 / 33$ / PBI / 2009, which is still used today by Islamic Banks in
accordance Reports and Assessment GCG Implementation Paragraph 1 GCG
Implementation Report Article 62. The method used is descriptive qualitative
research more emphasis on estimates rather than measurements. The author
chose a descriptive study for the provision of information required in the form of
relevant references and data taken in the form of a reportof corporate governance
(GCG) in the period 2015. The population is the state-owned Commercial
Bank Syariah. The samples are BNI Syariah and BRISyariah. Judging from the
results of the implementation of Good Corporate Governance and disclosure,
especially in the second Sharia Commercial Bank BNI Syariah and BRISyariah


the implementation of good corporate governance in the future should be run more effectively and thus has a score / rating GCG high. In addition, the implementation of good corporate governance and disclosure must conform in accordance with the principles of Good Corporate Governance itself, namely transparency, accountability, responsibility, independence and fairness.

\section{Keywords: Implementation of Good Corporate Governance and Disclosure}

\section{PENDAHULUAN}

Kasus Bank Century sempat menjadi trending topic beberapa tahun yang lalu. Begitu banyak permasalahan terkait dengan Bank Century. Pertama, menurut Maryono, manajemen Bank Century melakukan kesalahan terkait pengelolaan aset seperti deposito jaminan. Kedua, tidak memelihara Giro Wajib Minimum, dan ketiga terang dia, kepemilikan Surat-Surat Berharga (SSB) yang berkualitas rendah. Menurutnya tiga hal itu yang menyebabkan Century selalu kesulitan menambah modal hingga sebelum kalah kliring pada 13 November 2008 . $^{1}$

Dengan berbagai permasalahannya, Bank Century ditetapkan menjadi bank gagal berdampak sistemik. Munculnya kasus Bank Century di tahun 2008 lalu, lebih disebabkan oleh buruknya manajemen bank/tata kelola perusahaan. Selain itu jauh sebelum kasus Bank Century merebak, krisis perbankan di Indonesia pada tahun 1997 lalu juga telah membuat sejumlah bank kolaps.

Krisis perbankan di Indonesia yang dimulai akhir tahun 1997 bukan sematamata diakibatkan oleh krisis ekonomi, tetapi juga diakibatkan oleh belum dilaksanakannya good corporate governance dan etika yang melandasinya. Oleh karena itu, usaha mengembalikan kepercayaan kepada dunia perbankan Indonesia melalui restrukturisasi dan rekapitalisasi hanya dapat mempunyai dampak jangka panjang dan mendasar apabila disertai tiga tindakan penting lain yaitu : (i) Ketaatan terhadap prinsip kehati-hatian; (ii) Pelaksanaan good corporate governance; dan (iii) Pengawasan yang efektif dari Otoritas Pengawas Bank. ${ }^{2}$

Tata kelola perusahaan yang buruk mengakibatkan perusahaan rentan akan berbagai masalah dan tidak bisa bertahan dalam jangka waktu yang lama. Buruknya tata kelola perusahaan tentu erat kaitannya dengan manajemen yang buruk. Manajemen yang buruk tentunya berpengaruh pada pengelolaan keuangan perusahaan itu sendiri. Hal ini terbukti dengan adanya krisis ekonomi di Indonesia beberapa tahun yang lalu. Banyak perusahaan yang merugi dan tidak bisa bertahan karena tata kelola perusahaan yang buruk tersebut.

Beberapa hasil assessment terhadap corporate governance di Indonesia, menunjukan hasil yang belum memuaskan dan upaya perbaikan corporate governance belum dilakukan secara komprehensif. ${ }^{3} \mathrm{Hal}$ ini menjadi pelajaran terutama dalam dunia perbankan agar lebih berhati-hati dalam mengelola perusahaannya. Oleh karena itu penerapan Good Corporate Governance harus ditingkatkan khususnya di dunia perbankan baik bank konvensional dan khususnya bank syariah.

Peningkatan kualitas pelaksanaan good corporate governance merupakan salah satu upaya untuk memperkuat industri perbankan Nasional sesuai dengan Arsitektur Perbankan Indonesia. ${ }^{4}$ Untuk mendukung pelaksanaan Good Corporate Governance pada Bank Umum Syariah dan

1 http://www.tribunnews.com/nasional/2014/04/28/bank-century-punya-tiga-masalah-utama, diunduh Desember 2016

2 Pedoman Good Corporate Governance Perbankan Indonesia Dikeluarkan oleh: Komite Nasional Kebijakan Corporate Governance, Januari 2004.

3 Disampaikan oleh Etty Retno Wulandari (Advisor Senior - OJK) pada diskusi Panel "Transformasi Budaya Korporasi Melalui Good Corporate Governance” Universitas Trisakti, 11 Desember 2014, dalam Hamdani, Good Corporate Governance: Tinjauan Etika dalam Praktik Bisnis. Jakarta: Mitra Wacana Media, 2016, h-194.

4 Peraturan Bank Indonesia Nomor 8/14/PBI/2006 Tentang Perubahan Atas Peraturan Bank Indonesia Nomor 8/4/PBI/2006 Tentang Pelaksanaan Good Corporate Governance Bagi Bank Umum, dalam Hamdani, Good Corporate Governance: Tinjauan Etika dalam Praktik Bisnis. Jakarta: Mitra Wacana Media, 2016, h-190. 
Unit Usaha Syariah, saat ini terkait dengan penerapan Good Corporate Governance pada Bank Umum Syariah dan Unit Usaha Syariah dikeluarkanlah Surat Edaran Bank Indonesia No. 12/13/ DPbs/2010 tentang Pelaksanaan Good Corporate Governance bagi Bank Umum Syariah dan Unit Usaha Syariah sebagai penyempurna dari Peraturan Bank Indonesia Nomor 11/33/PBI/2009.

Dalam praktiknya, umumnya Bank Umum Syariah masih menggunakan Peraturan Bank Indonesia Nomor 11/33/PBI/2009 sebagai pedoman pelaksaanan Good Corporate Governance meskipun sudah mulai menerapkan Surat Edaran Bank Indonesia No. 12/13/DPbs/2010 secara bertahap. Oleh karena itu studi ini membahas mengenai pelaksanaan Good Corporate Governance dan pengungkapannya khususnya di BNI Syariah dan BRISyariah sesuai dengan Peraturan Bank Indonesia Nomor 11/33/PBI/2009.

\section{PERUMUSAN MASALAH} berikut:

Berdasarkan latar belakang penelitian di atas, maka penulis merumuskan masalah sebagai

1. Bagaimana pelaksanaan Good Corporate Governance pada BNI Syariah dan BRISyariah.

2. Bagaimana pengungkapan Good Corporate Governance pada BNI Syariah dan BRISyariah.

3. Bagaimana pengaruh pelaksanaan Good Corporate Governance terhadap pengungkapan Good Corporate Governance pada BNI Syariah dan BRISyariah.

\section{METODE PENELITIAN}

Metode penelitian yang digunakan adalah penelitian kualitatif yang secara deskriptif lebih menekankan pada perkiraan daripada pengukuran. Penulis memilih studi deskriptif karena penyediaan informasi yang dibutuhkan berupa referensi-referensi terkait dan data yang diambil berupa laporan tata kelola perusahaan (Good Corporate Governance) periode 2015. Populasi yang diambil adalah Bank Umum Syariah milik BUMN. Sampel yang digunakan adalah BNI Syariah dan BRISyariah.

\section{TINJAUAN PUSTAKA}

\section{Good Corporate Governance}

Prinsip GCG yaitu transparansi, akuntabilitas, responsibilitas, independensi serta kewajaran dan kesetaraan diperlukan unuk mencapai kesinambungan usaha (sustainability) perusahaan dengan memperhatikan pemangku kepentingan (stakeholders). ${ }^{5}$ Adapun uraian prinsip-prinsip Good Corporate Governance (GCG) yang berlaku secara umum diantaranya:

a. Transparansi

Transparansi merupakan suatu komitmen untuk memastikan ketersediaan dan keterbukaan informasi penting bagi pihak-pihak yang berkepentingan (stakeholders) mengenai keadaan keuangan, pengelolaan dan kepemilikan Perseroan secara akurat, jelas dan tepat waktu. ${ }^{6}$ Transparansi (transparency) mengandung unsur pengungkapan (disclosure) dan penyediaan informasi secara tepat waktu, memadai, jelas, akurat, dan dapat diperbandingkan serta mudah diakses oleh pemangku kepentingan dan masyarakat. (Komite Nasional Kebijakan Governance, 2011). ${ }^{7}$ Beeks dan Brown (2005) ${ }^{8}$ menemukan bahwa perusahaan dengan kualitas good corporate governance membuat pengungkapan lebih informatif. Keuntungan dari transparansi yang bagus dan pelaksanaan pengungkapan adalah:

$5 \quad$ Komite Nasional Kebijakan Governance, 2006.

6 Edi Wibowo, 2010, Implementasi Good Corporate Governance di Indonesia. Jurnal ekonomi dan Kewirausahaan Vol. 10, No. 2, Oktober 2010.

$7 \quad$ Komite Nasional Kebijakan Governance, Pedoman Umum Good Governance Bisnis Syariah, 2011.

8 N. Baydoun, and Willett R.. "Islamic Accounting Theory”, Proceeding of AAANZ Annual Conference, Sydney, Australia, 1994. 
1) Meminimalisir asimetri informasi dalam perusahaan dan kemungkinan kecurangan.

2) Meningkatkan kepedulian investor yang akan mengurangi ketidakpastian dalam pengembalian atas ketersediaan modal, yang diharapkan pula akan mengurangi biaya perusahaan terhadap modal luar dan meningkatkan nilai-nilai yang ada. ${ }^{9}$

b. Akuntabilitas

Prinsip akuntabilitas adalah prinsip di mana para pengelola berkewajiban untuk membina sistem akuntansi yang efektif untuk menghasilkan laporan keuangan (financial statements) yang dapat dipercaya. Untuk itu, diperlukan kejelasan fungsi, pelaksanaan, dan pertanggungjawaban setiap organ sehingga pengelolaan berjalan efektif. ${ }^{10}$

c. Responsibilitas

Prinsip responsibilitas (lebih sering disebut prinsip tanggung jawab) adalah prinsip dimana para pengelola wajib memberikan pertanggungjawaban atas semua tindakan dalam mengelola perusahaan kepada para pemangku kepentingan sebagai wujud kepercayaan yang diberikan kepadanya. ${ }^{11}$

d. Indepedensi

Prinsip dasar independensi (independency) dalam pelaksanaan GCG bagi perusahaan diharapkan pengelolaan dapat dilakukan secara independen sehingga masing-masing organ perusahaan tidak saling mendominasi dan tidak dapat diintervensi oleh pihak lain. 12

e. Kesetaraan

Prinsip kewajaran dan kesetaraan adalah prinsip yang mengandung unsur keadilan, yang menjamin bahwa setiap keputusan dan kebijakan yang diambil adalah demi kepentingan seluruh pihak yang berkepentingan, termasuk para pelanggan, pemasok, pemegang saham, investor serta masyarakat luas. ${ }^{13}$ Terlebih keadilan dan perlidungan terhadap kepentingan pemegang saham minoritas dari tindakan kecurangan. ${ }^{14}$

\section{Good Corporate Governance Dalam Bank Syariah}

Ada dua asas dalam implementasi GCG pada perbankan syariah di Indonesia yaitu asas Shifat dan Tarik. Asas Shifat seperti yang dicontohkan Nabi Muhammad SAW dalam aktivitas bisnis yaitu Shidiq, fathonah, amanah dan tablig. Asas kedua adalah Tarik, dipakai dalam dunia usaha pada umumnya yaitu transparansi, akuntabilitas, responsibilitas, independensi serta kewajaran dan kesetaraan. Kedua asas operasional tersebut diperlukan untuk mencapai kesinambungan (sustainability) dengan memperhatikan kepentingan para pemangku kepentingan (stakeholders). ${ }^{15}$ Ada beberapa persoalan mengenai praktik GCG di Indonesia yaitu sebagai berikut:

9 Kasri, Irma Aulia R. dan Niki Lukviarman. "Governance and Corporate Disclosure: A Study in Bank Muamalat Indonesia and Bank Syariah Mandiri”, dalam kumpulan Makalah Call for Paper yang lulus dalam seleksi Panitia International Seminar and Symposium on Implementation of Islamic Economics to Positive Economics in The World as Alternative of Conventional Economics System: Toward Development in The New Era, 2008. of The Holistic Economics, Unair, 1-2 Agustus 2008.

10 Sukrisno Agoes dan I Cenik Ardana, Etika Bisnis dan Profesi: Tantangan Membangun Manusia Seutuhnya. Jakarta: Salemba Empat, 2014, h-104.

11 ibid

12 Hamdani, Good Corporate Governance: Tinjauan Etika dalam Praktik Bisnis. Jakarta: Mitra Wacana Media, 2016, $h-76$.

13 Edi Wibowo, 2010, Implementasi Good Corporate Governance di Indonesia. Jurnal ekonomi dan Kewirausahaan Vol. 10, No. 2, Oktober 2010.

14 Khomsiyah, Analisis Hubungan Indeks dan Struktur Corporate Governance dengan Kualitas Pengungkapan, Disertasi universitas Gadjah Mada Yogyakarta, 2005.

15 Hamdani, Good Corporate Governance: Tinjauan Etika dalam Praktik Bisnis. Jakarta: Mitra Wacana Media, 2016, h 194-195. 
a. Belum profesionalnya pengelolaan perusahaan (ADB, 1998). Konsentrasi kepemilikan oleh pihak tertentu yang memungkinkan terjadinya hubungan afiliasi antara pemilik, pengawas, dan direktur perusahaan serta belum berfungsinya dewan komisaris. ${ }^{16}$

b. Konsentrasi kepemilikan dan kontrol meningkatkan ketidaksimetrisan informasi antara pemegang saham mayoritas dan pemegang saham minoritas akan menyulitkan pemegang saham minoritas untuk berpartisipasi dalam pengambilan keputusan. ${ }^{17}$

c. Konsentrasi kepemilikan dan kontrol juga menyebabkan lemahnya proteksi hukum bagi pemegang saham minoritas. ${ }^{18}$

d. Score keterbukaan yang rendah.

Kendala penerapan GCG di Indonesia dibagi kedalam tiga bagian, yaitu kendala internal, kendala eksternal, dan kendala yang berasal dari struktur kepemilikan. ${ }^{19}$

a. Kendala internal, meliputi: kurangnya komitmen dari pimpinan dan karyawan perusahaan, rendahnya tingkat pemahamam dari pimpinan dan karyawan perusahaan tentang prinsipprinsip good corporate governance, kurangnya panutan atau teladan yang diberikan oleh pimpinan, belum adanya budaya perusahaan yang mendukung terwujudnya prinsipprinsip good corporate governance, serta belum efektifnya sistem pengendalian internal. 20

b. Kendala eksternal dalam pelaksanaan corporate governance terkait dengan perangkat hukum, aturan dan penegakan hukum (law enforcement). Secara implisist ketentuanketentuan mengenai GCG telah ada tersebar dalam UUPT, Undang-undang dan Peraturan Perbankan, Undang-undang Pasar Modal dan lain-lain. Namun penegakannya oleh pemegang otoritas, seperti Bank Indonesia, Bapepam, BPPN, Kementerian Keuangan, BUMN, bahkan pengadilan sangat lemah.

c. Kendala yang berasal dari struktur kepemilikan. Berdasarkan persentasi kepemilikan dalam saham, kepemilikan terhadap perusahaan dapat dibedakan menjadi dua, yaitu kepemilikan yang terkonsentrasi dan kepemilikan yang menyebar. Kepemilikan yang terkonsentrasi akan didominasi oleh seseorang atau sekelompok orang saja $(40,00 \%$ atau lebih). Kepemilikan yang menyebar terjadi pada saat suatu perusahaan dimiliki oleh pemegang saham yang banyak dengan jumlah saham yang kecil-kecil (satu pemegang saham hanya memiliki saham sebesar 5\% atau kurang). Salah satu dampak negatif yang ditimbulkan oleh struktur kepemilikan adalah perusahaan tidak dapat mewujudkan prinsip keadilan dengan baik karena pemegang saham yang terkonsentrasi pada seseorang atau sekelompok orang dapat menggunakan sumber daya perusahaan secara dominan sehingga dapat mengurangi nilai perusahaan. ${ }^{21}$

16 Herwidayatmo, 2001, dalam Hamdani, Good Corporate Governance: Tinjauan Etika dalam Praktik Bisnis. Jakarta: Mitra Wacana Media, 2016, h-122.

17 S. Utama, Corporate Governance, Disclosure dan Its Evidence In Indonesia. Part I, Usahawan No. 04, Tahun XXXII, April 2003, dalam Hamdani, 2016, Good Corporate Governance: Tinjauan Etika dalam Praktik Bisnis. Jakarta: Mitra Wacana Media, 2016, h-123.

18 ibid

19 Edi Wibowo, 2010, Implementasi Good Corporate Governance di Indonesia. Jurnal ekonomi dan Kewirausahaan Vol. 10, No. 2, Oktober 2010, dalam Hamdani, 2016, Good Corporate Governance: Tinjauan Etika dalam Praktik Bisnis. Jakarta: Mitra Wacana Media, 2016, h-123.

20 H.E. Djatmiko, 2004, dalam Hamdani, 2016, h-123.

21 Hamdani, 2016, Good Corporate Governance: Tinjauan Etika dalam Praktik Bisnis. Jakarta: Mitra Wacana Media, 2016, h-123. 


\section{Pengungkapan Good Corporate Governance}

Sama halnya dengan pelaksanaan Good Corporate Governance, pengungkapan Good Corporate Governance Bank Umum Syariah ini mengacu pada Peraturan Bank Indonesia Nomor 11/33/PBI/2009 yang masih digunakan hingga saat ini oleh Bank Umum Syariah sesuai Laporan dan Penilaian Pelaksanaan GCG Paragraf 1 Laporan Pelaksanaan GCG Pasal 62 yaitu sebagai berikut: ${ }^{22}$

a. BUS wajib menyusun laporan pelaksanaan GCG pada setiap akhir tahun buku.

b. Laporan pelaksanaan GCG sebagaimana dimaksud pada ayat (1), paling kurang meliputi

1) kesimpulan umum dari hasil self assesment atas pelaksanaan GCG BUS;

2) kepemilikan saham anggota Dewan Komisaris, hubungan keuangan dan hubungan keluarga anggota Dewan Komisaris dengan pemegang saham pengendali, anggota Dewan Komisaris lain dan/atau anggota Direksi BUS serta jabatan rangkap pada perusahaan atau lembaga lain sebagaimana dimaksud dalam Pasal 16;

3) kepemilikan saham anggota Direksi serta hubungan keuangan dan hubungan keluarga anggota Direksi dengan pemegang saham pengendali, anggota Dewan Komisaris dan/atau anggota Direksi lain sebagaimana dimaksud dalam Pasal 32;

4) rangkap jabatan sebagai anggota Dewan Pengawas Syariah pada lembaga keuangan syariah lainnya sebagaimana dimaksud dalam Pasal 50;

5) daftar konsultan, penasihat atau yang dipersamakan dengan itu yang digunakan oleh BUS sebagaimana dimaksud dalam Pasal 27;

6) kebijakan remunerasi dan fasilitas lain (remuneration package) bagi Dewan Komisaris, Direksi, dan Dewan Pengawas Syariah sebagaimana dimaksud dalam Pasal 17 ayat (3), Pasal 33 ayat (3) dan Pasal 51 ayat (3);

7) rasio gaji tertinggi dan gaji terendah;

8) frekuensi rapat Dewan Komisaris sebagaimana dimaksud dalam Pasal 14 ayat (1);

9) frekuensi rapat Dewan Pengawas Syariah sebagaimana dimaksud dalam Pasal 49 ayat (1);

10) jumlah penyimpangan (internal fraud) yang terjadi dan upaya penyelesaian oleh BUS;

11) jumlah permasalahan hukum baik perdata maupun pidana dan upaya penyelesaian oleh BUS;

12) transaksi yang mengandung benturan kepentingan;

13) buy back shares dan/atau buy back obligasi BUS;

14) penyaluran dana untuk kegiatan sosial baik jumlah maupun pihak penerima dana; dan

15) pendapatan non halal dan penggunaannya.

c. Pengungkapan kebijakan remunerasi dan fasilitas lain (remuneration package) bagi Dewan Komisaris, Direksi, dan Dewan Pengawas Syariah sebagaimana dimaksud pada ayat (2) huruf f paling kurang mencakup jumlah anggota Dewan Komisaris, jumlah anggota Direksi, jumlah anggota Dewan Pengawas Syariah serta jumlah keseluruhan gaji, tunjangan (benefits), kompensasi dalam bentuk saham, bentuk remunerasi lainnya dan fasilitas yang ditetapkan Rapat Umum Pemegang Saham.

22 Peraturan Bank Indonesia Nomor 11/33/PBI/2009 Tentang Pelaksanaan Good Corporate Governance Bagi Bank Umum Syariah Dan Unit Usaha Syariah. 
HASIL DAN PEMBAHASAN

1. Hasil Penelitian

a. Pelaksanaan Good Corporate Governance Secara Umum Pada BNI Syariah dan BRISyariah Periode 2015

Tabel 1. Pelaksanaan Good Corporate Governance Secara Umum

\begin{tabular}{|c|c|c|c|}
\hline No. & Pelaksanaan Good Corporate Governance Secara Umum & $\begin{array}{l}\text { BNI } \\
\text { Syariah }\end{array}$ & $\begin{array}{c}\text { BRI } \\
\text { Syariah }\end{array}$ \\
\hline 1. & $\begin{array}{l}\text { Pelaksanaan tugas dan tanggung } \\
\text { jawab Dewan Komisaris }\end{array}$ & $\mathrm{V}$ & $\mathrm{V}$ \\
\hline 2. & Pelaksanaan tugas dan tanggung jawab Direksi & $\mathrm{V}$ & $\mathrm{V}$ \\
\hline 3. & Kelengkapan dan pelaksanaan tugas Komite & $\mathrm{V}$ & $\mathrm{V}$ \\
\hline 4. & Pelaksanaan tugas dan tanggung jawab Dewan Pengawas Syariah & $\mathrm{V}$ & $\mathrm{V}$ \\
\hline 5. & $\begin{array}{l}\text { Pelaksanaan Prinsip Syariah dalam kegiatan penghimpunan dana dan } \\
\text { penyaluran dana serta pelayanan jasa }\end{array}$ & V & $\mathrm{V}$ \\
\hline 6. & Penanganan benturan kepentingan & $\mathrm{V}$ & $\mathrm{V}$ \\
\hline 7. & Penerapan fungsi kepatuhan & $\mathrm{V}$ & $\mathrm{V}$ \\
\hline 8. & Penerapan fungsi audit intern & $\mathrm{V}$ & $\mathrm{V}$ \\
\hline 9. & Penerapan fungsi audit ekstern & $\mathrm{V}$ & $\mathrm{V}$ \\
\hline 10. & Batas Maksimum Penyaluran Dana & $\mathrm{V}$ & $\mathrm{V}$ \\
\hline 11. & $\begin{array}{l}\text { Transparansi kondisi keuangan dan non keuangan BUS, laporan } \\
\text { pelaksanaan GCG serta pelaporan internal }\end{array}$ & V & $\mathrm{V}$ \\
\hline
\end{tabular}

b. Pengungkapan Good Corporate Governance Dua Bank Umum Syariah Periode 2015

Tabel 2. Indikator Pengungkapan Good Corporate Governance

\begin{tabular}{lllcc}
\hline No & \multicolumn{2}{c}{ Indikator Pengungkapan Good Corporate Governance } & $\begin{array}{c}\text { BNI } \\
\text { Syariah }\end{array}$ & $\begin{array}{c}\text { BRI } \\
\text { Syariah }\end{array}$ \\
\hline 1. & Kesimpulan Umum & Hasil self assessment GCG & $\mathrm{V}$ & $\mathrm{V}$ \\
\multirow{2}{*}{ 2. } & \multirow{2}{*}{ Kepemilikan Saham } & Dewan Komisaris & $\mathrm{V}$ & $\mathrm{V}$ \\
& & Direksi & - & - \\
& & Dewan Komisaris & $\mathrm{V}$ & $\mathrm{V}$ \\
3. & Hubungan Keuangan & Pemegang Saham Pengendali & $\mathrm{V}$ & $\mathrm{V}$ \\
& & Direksi & $\mathrm{V}$ & $\mathrm{V}$ \\
\hline
\end{tabular}




\begin{tabular}{|c|c|c|c|c|}
\hline No & Indikator Pengungk: & pan Good Corporate Governance & $\begin{array}{c}\text { BNI } \\
\text { Syariah }\end{array}$ & $\begin{array}{c}\text { BRI } \\
\text { Svariah }\end{array}$ \\
\hline \multirow{3}{*}{4.} & \multirow{3}{*}{ Hubungan Keluarga } & Dewan Komisaris & $\mathrm{V}$ & $\mathrm{V}$ \\
\hline & & Pemegang Saham Pengendali & $\mathrm{V}$ & $\mathrm{V}$ \\
\hline & & Direksi & V & V \\
\hline \multirow{3}{*}{5.} & \multirow{3}{*}{ Rangkap Jabatan } & Dewan Komisaris & V & $\mathrm{V}$ \\
\hline & & Dewan Pengawas Syariah & V & $\mathrm{V}$ \\
\hline & & Proyek bersifat khusus & - & $\mathrm{V}$ \\
\hline \multirow[t]{2}{*}{6.} & \multirow[t]{2}{*}{$\begin{array}{l}\text { Daftar Konsultan, } \\
\text { Penasihat }\end{array}$} & $\begin{array}{l}\text { Tujuan, ruang lingkup kerja, tanggung } \\
\text { jawab, jangka waktu pelaksanaan dan } \\
\text { biaya }\end{array}$ & - & - \\
\hline & & $\begin{array}{l}\text { Independen profesional dan kualifikasi } \\
\text { yang cukup }\end{array}$ & - & V \\
\hline \multirow{8}{*}{7.} & \multirow{8}{*}{$\begin{array}{l}\text { Kebijakan Remunerasi dan } \\
\text { Fasilitas Lain }\end{array}$} & Jumlah anggota Dewan Komisaris & $\mathrm{V}$ & - \\
\hline & & Jumlah anggota Direksi & V & - \\
\hline & & $\begin{array}{l}\text { Jumlah anggota Dewan Pengawas } \\
\text { Syariah }\end{array}$ & V & - \\
\hline & & Jumlah seluruh gaji & $\mathrm{V}$ & - \\
\hline & & Jumlah tunjangan & $\mathrm{V}$ & - \\
\hline & & Kompensasi dalam bentuk saham & - & _ \\
\hline & & Remunerasi lainnya & $\mathrm{V}$ & - \\
\hline & & Fasilitas yang ditetapkan RUPS & V & - \\
\hline 8. & Rasio Gaji & Rasio gaji tertinggi dan terendah & - & - \\
\hline \multirow{3}{*}{9.} & \multirow{3}{*}{$\begin{array}{l}\text { Frekuensi Rapat Dewan } \\
\text { Komisaris }\end{array}$} & $\begin{array}{l}\text { Wajib diselenggarakan paling kurang } 1 \\
\text { (satu) kali dalam } 2 \text { (dua) bulan }\end{array}$ & V & $\mathrm{V}$ \\
\hline & & $\begin{array}{l}\text { Wajib dihadiri paling kurang } 2 / 3 \text { dari } \\
\text { jumlah anggota Dewan Komisaris }\end{array}$ & V & $\mathrm{V}$ \\
\hline & & Wajib dipimpin oleh Komisaris Utama & $\mathrm{V}$ & $\mathrm{V}$ \\
\hline 10. & $\begin{array}{l}\text { Frekuensi Rapat Dewan } \\
\text { Pengawas Syariah }\end{array}$ & $\begin{array}{l}\text { Jumlah rapat wajib diselenggarakan } \\
\text { paling kurang } 1 \text { (satu) kali dalam } 1 \\
\text { (satu) bulan }\end{array}$ & V & $\mathrm{V}$ \\
\hline \multirow{2}{*}{11.} & \multirow{2}{*}{$\begin{array}{l}\text { Jumlah Penyimpangan } \\
\text { (Internal Fraud) }\end{array}$} & Jumlah penyimpangan yang terjadi & V & - \\
\hline & & Upaya penyelesaian & V & - \\
\hline 12. & $\begin{array}{l}\text { Jumlah Permasalahan } \\
\text { Hukum dan Upaya } \\
\text { Penyelesaian }\end{array}$ & $\begin{array}{l}\text { Jumlah permasalahan hukum perdata } \\
\text { dan pidana yang dihadapi dan upaya } \\
\text { penyelesaiannya }\end{array}$ & V & - \\
\hline 13. & $\begin{array}{l}\text { Transaksi yang } \\
\text { Mengandung Benturan } \\
\text { Kepentingan }\end{array}$ & & V & V \\
\hline 14. & $\begin{array}{l}\text { Buy Back Shares dan/atau } \\
\text { Buy Back Obligation }\end{array}$ & & V & - \\
\hline \multirow{2}{*}{15.} & \multirow{2}{*}{$\begin{array}{l}\text { Penyaluran Dana untuk } \\
\text { Kegiatan Sosial }\end{array}$} & Jumlah & $\mathrm{V}$ & $\mathrm{V}$ \\
\hline & & Pihak Penerima Dana & - & V \\
\hline \multirow{2}{*}{16.} & Pendapatan Non Halal dan & Pendapatan Non Halal & V & - \\
\hline & Penggunaannya & Penggunaannya & V & - \\
\hline
\end{tabular}




\section{PEMBAHASAN}

\section{Analisi BNI Syariah}

\section{a. Kesimpulan Umum}

Pada tahun 2015, BNI Syariah telah melaksanakan self assessment dan berdasarkan hasil self assessment BNI Syariah dapat disimpulkan bahwa manajemen BNI Syariah telah melaksanakan GCG secara umum dengan"BAIK". Meski berdasarkan hasil self assessment BNI Syariah dianggap baik namun BNI Syariah tidak memberi keterangan skor penilaian Good Corporate Governance tersebut.

1) Kepemilikan Saham

Dalam hal kepemilikan saham, Dewan Komisaris dan Direksi BNI Syariah tidak memiliki saham baik di BNI Syariah itu sendiri maupun di perusahaan lain. Meski demikian BNI Syariah tetap mengungkapkan kepemilikan saham tersebut.

2) Hubungan Keuangan

Dewan Komisaris, Pemegang Saham Pengendali dan Direksi, satu sama lain tidak memiliki hubungan keuangan (independen). Meski demikian BNI Syariah tetap mengungkapkan hubungan keuangan tersebut.

3) Hubungan Keluarga

Dewan Komisaris, Pemegang Saham Pengendali dan Direksi, satu sama lain tidak memiliki hubungan keluarga (independen). Meski demikian BNI Syariah tetap mengungkapkan hubungan keluarga tersebut.

4) Rangkap Jabatan

Rangkap Jabatan pada BNI Syariah terjadi pada Komite Audit BNI Syariah terdiri dari 5 (lima) orang anggota, 2 (dua) orang anggota merupakan Komisaris Independen yang salah satunya menjabat sebagai Ketua Komite, 1 (satu) orang Komisaris sebagai anggota, dan 2 (dua) orang pihak independen sebagai anggota. Rangkap jabatan Komite Audit telah memperhatikan kompetensi, kriteria independensi, kerahasiaan, kode etik serta pelaksanaan tugas dan tanggung jawab masing-masing sesuai ketentuan yang berlaku. Selain itu rangkap jabatan juga terjadi pada Dewan Pengawas Syariah (DPS) dimana Ketua dan Anggota DPS merangkap jabatan pada perusahaan lainnya (Bank Syariah dan Unit Usaha Syariah lainnya).

5) Daftar Konsultan, Penasihat

Pada BNI Syariah tidak mengungkapkan mengenai daftar nama perusahaan konsultan, tujuan, ruang lingkup kerja dan nama konsultan, penasihat itu sendiri.

6) Kebijakan Remunerasi dan Fasilitas Lain

BNI Syariah telah menetapkan dan mengungkapkan kebijakan remunerasi dan fasilitas lain per jabatan dalam 1 tahun, baik untuk Dewan Komisaris, Direksi dan Dewan Pengawas Syariah.

7) Rasio Gaji

BNI Syariah tidak mengungkapkan rasio gaji Pegawai, Direksi dan Komisaris.

8) Frekuensi Rapat Dewan Komisaris

Jumlah rapat Dewan Komisaris dalam 1 (satu) tahun sebanyak 49 kali sepanjang tahun 2015. Dewan Komisaris telah melakukan rapat sebanyak 49 (empat puluh sembilan) kali, dengan rincian 34 kali Rapat Dewan Komisaris, dan 15 kali rapat dengan Direksi.

9) Frekuensi Rapat Dewan Pengawas Syariah

Rapat Dewan Pengawas Syariah (DPS) minimal dilakukan sebulan sekali. Sepanjang tahun 2015, DPS telah melakukan rapat sebanyak 15 kali dengan tingkat kehadiran rapat yang sama. 
10) Jumlah Penyimpangan (Internal Fraud)

Sepanjang tahun 2015, penyimpangan (internal fraud) yang terjadi sebanyak 2 kasus dan telah diselesaikan.

11) Jumlah Permasalahan Hukum dan Upaya Penyelesaian

Sampai dengan 31 Desember 2015, penyelesaian perkara hukum yang dihadapi oleh BNI Syariah terdapat 27 perkara hukum. Dari 27 perkara tersebut, perkara perdata aktif/dalam proses penyelesaian sejumlah 17 perkara dan perkara pidana aktif berjumlah 1 perkara sedangkan perkara yang sudah memiliki kekuatan hukum tetap/inkracht sejumlah 9 perkara. Perkara tersebut disebabkan oleh adanya gugatan hukum kepada BNI Syariah mayoritas dilakukan oleh nasabah yang pembayarannya macet dan keberatan terhadap agunannya yang akan dieksekusi lelang oleh BNI Syariah.

12) Transaksi yang Mengandung Benturan Kepentingan

Tidak ada pengungkapan mengenai transaksi yang mengandung benturan kepentingan. Meski demikian BNI Syariah tetap mengungkapkannya.

13) Buy Back Shares dan/atau Buy Back Obligasi

Buy back shares atau buy back obligation adalah upaya mengurangi jumlah saham atau obligasi yang telah diterbitkan Bank dengan cara membeli kembali saham atau obligasi tersebut dengan tata cara pembayaran yang dilaksanakan sesuai dengan ketentuan yang berlaku. Selama tahun 2015 BNI Syariah tidak melakukan transaksi buy back shares atau buy back obligation. Meski demikian, BNI Syariah tetap mengungkapkan kebijakan buy back shares dan/atau buy back obligation tersebut.

14) Penyaluran Dana untuk Kegiatan Sosial

BNI Syariah menyalurkan dana untuk kegiatan sosial yang berasal dari dana nonzakat yang berasal dari pendapatan non halal seperti denda dan pendapatan non halal lainnya yang masuk sebagai dana kebajikan. Selain itu BNI Syariah mengungkapkan jumlah nominal yang disalurkan sepanjang tahun 2015 namun pengungkapan pihak penerima dana tersebut tidak diungkapkan dengan jelas pada laporan tata kelola perusahaan / Good Corporate Governance.

15) Pendapatan Non Halal dan Penggunaannya

Sumber pendapatan Non Halal berasal dari denda keterlambatan (penalty) pembayaran angsuran atau denda lain yang berhubungan dengan transaksi antar pihak Bank dengan pihak ketiga dan pendapatan non halal BNI Syariah lain seperti penempatan giro dan penempatan dalam bentuk lainnya pada bank konvensional yang masuk dalam dana kebajikan. BNI Syariah mengungkapkan pula nilai dan penggunaan dari pendapatan non halal tersebut. Penggunaan dana tersebut disalurkan pada program-program sosial yang telah ditetapkan BNI Syariah.

Dapat disimpulkan bahwa dilihat dari pelaksanaan Good Corporate Governance BNI Syariah dan pengungkapannya dapat diketahui bahwa BNI Syariah telah melaksanakan Good Corporate Governance dengan "BAIK" meski ada beberapa item/ indikator pengungkapan yang tidak dimasukkan dalam laporan tata kelola perusahaan/ Good Corporate Governance.

\section{b. Analisis BRISyariah}

1) Kesimpulan Umum

Untuk periode tahun 2015, Bank BRISyariah menyimpulkan pelaksanaan GCG dengan predikat "Baik" yang mencerminkan keberhasilan yang cukup baik pada semua faktor pelaksanaan GCG dengan skor 1,61. 
2) Kepemilikan Saham

Dewan Komisaris tidak memiliki saham yang mencapai 5\% (lima persen) atau lebih dari modal disetor di BRISyariah sedangkan Direksi tidak memiliki satu pun saham di BRISyariah.

3) Hubungan Keuangan

Dewan Komisaris dalam hal ini yang menjabat sebagai Komisaris sebanyak 2 (dua) orang memiliki hubungan keuangan dengan Pemegang Saham Pengendali begitupula dengan 2 (dua) orang Direksi memiliki hubungan keuangan dengan Pemegang Saham Pengendali.

4) Hubungan Keluarga

Dewan Komisaris, Pemegang Saham Pengendali dan Direksi, satu sama lain tidak memiliki hubungan keluarga (independen).

5) Rangkap Jabatan

Rangkap jabatan pada Dewan Komisaris di BRISyariah diantaranya:

a) 1 (satu) Komisaris Independen sebagai Wakil Rektor IPB Bogor

b) 1 (satu) Komisaris Independen sebagai Ketua DPS PT. Bank Syariah Mandiri

c) 1 (satu) Komisaris sebagai Chief Economist PT. Bank Rakyat Indonesia (Persero) Tbk.

d) 1 (satu) Komisaris sebagai Kepala Divisi Kebijakan SDM PT. Bank Rakyat Indonesia (Persero) Tbk.

Rangkap jabatan pada Dewan Pengawas Syariah di BRISyariah diantaranya:

a) 1 (satu) Ketua Dewan Pengawas Syariah sebagai Chairman BPRS Amanah Ummat dan Permodalan Nasional Madani (PNM).

b) 1 (satu) Anggota Dewan Pengawas Syariah sebagai Anggota DPS PT Asuransi Astra Buana, Jamkrindo (perum) dan BPRS Harta Insan Karimah.

6) Daftar Konsultan, Penasihat

Dengan mempertimbangkan rekomendasi dari Komite Audit, penunjukan Kantor Akuntan Publik yang sama dilakukan maksimal hanya 5 (lima) tahun buku berturut-turut dan Akuntan yang sama dari Kantor Akuntan Publik (KAP) tersebut diperkenankan melakukan audit selama 4 (empat) tahun buku berturut-turut. Untuk memenuhi standar profesional, KAP yang ditunjuk adalah KAP yang sudah terdaftar di Bank Indonesia dan termasuk 5 KAP terbaik, yaitu KAP Purwantono, Sungkoro, Surja, anggota Ernst \& Young Global.

7) Kebijakan Remunerasi dan Fasilitas Lain

BRISyariah tidak menetapkan dan mengungkapkan kebijakan remunerasi dan fasilitas lain baik untuk Dewan Komisaris, Direksi dan Dewan Pengawas Syariah.

8) Rasio Gaji

BRISyariah tidak mengungkapkan rasio gaji tertinggi dan terendah.

9) Frekuensi Rapat Dewan Komisaris

Jumlah rapat Dewan Komisaris dalam 1 (satu) tahun sebanyak 19 kali sepanjang tahun 2015.

10) Frekuensi Rapat Dewan Pengawas Syariah

Dalam melaksanakan tugas dan tanggung jawabnya, selama periode Tahun 2015 DPS telah melakukan rapat sebanyak 14 kali yang terdiri dari 12 kali rapat DPS dan 2 kali rapat Konsultatif.

11) Jumlah Penyimpangan (Internal Fraud)

Dalam laporan Good Corporate Governance BRISyariah tidak mengungkapkan mengenai jumlah penyimpangan (Internal Fraud) yang terjadi selama periode 2015 . 
12) Jumlah Permasalahan Hukum dan Upaya Penyelesaian BRISyariah tidak mengungkapkan item permasalahan hukum dan upaya penyelesaian dalam laporan Good Corporate Governance periode 2015.

13) Transaksi yang Mengandung Benturan Kepentingan

Tidak ada pengungkapan mengenai transaksi yang mengandung benturan kepentingan. Meski demikian BRISyariah tetap mengungkapkannya.

14) Buy Back Shares dan/atau Buy Back Obligasi

BRISyariah tidak mengungkapkan buy back shares dan/atau buy back obligasi dalam laporan Good Corporate Governance periode 2015.

15) Penyaluran Dana untuk Kegiatan Sosial

BRISyariah menyalurkan dana untuk kegiatan sosial yang berasal dari dana ZIS yang diberikan kepada BAZNAS dan lembaga sosial lain.

16) Pendapatan Non Halal dan Penggunaannya

BRISyariah tidak mengungkapkan pendapatan non halal dan penggunaannya dalam laporan Good Corporate Governance periode 2015.

Dapat disimpulkan bahwa dilihat dari pelaksanaan Good Corporate Governance BRI Syariah dan pengungkapannya dapat diketahui bahwa BRISyariah telah melaksanakan Good Corporate Governance dengan "BAIK"meski ada beberapa item/indikator pengungkapan yang tidak dimasukkan dalam laporan tata kelola perusahaan/Good Corporate Governance.

Dilihat dari hasil pelaksanaan dan pengungkapan Good Corporate Governance khususnya pada kedua Bank Umum Syariah yaitu BNI Syariah dan BRISyariah maka pelaksanaan Good Corporate Governance kedepannya harus berjalan lebih efektif dan tentunya memiliki score/rating GCG yang tinggi. Untuk memenuhi harapan tersebut maka perusahaan-perusahaan di Indonesia wajib melakukan: ${ }^{23}$

1) Pengelolaan perusahaan secara professional dan tidak memiliki hubungan afiliasi antara pemilik, pengawas, dan direktur perusahaan serta dewan komisaris.

2) Terciptanya hubungan yang simetris sehingga pemegang saham minoritas dapat berpartisipasi dalam pengambilan keputusan perusahaan.

3) Melakukan proteksi hukum bagi pemegang saham minoritas.

4) Meningkatkan score/rating keterbukaan.

Selain itu, pelaksanaan dan pengungkapan Good Corporate Governance harus sesuai sesuai dengan prinsip-prinsip Good Corporate Governance itu sendiri yaitu transparansi, akuntabilitas, responsibilitas, independensi serta kewajaran dan kesetaraan.

\section{KESIMPULAN}

Sama halnya dengan pelaksanaan Good Corporate Governance, pengungkapan Good Corporate Governance Bank Umum Syariah ini mengacu pada Peraturan Bank Indonesia Nomor 11/33/PBI/2009 yang masih digunakan hingga saat ini oleh Bank Umum Syariah sesuai Laporan dan Penilaian Pelaksanaan GCG Paragraf 1 Laporan Pelaksanaan GCG Pasal 62.

Dilihat dari hasil pelaksanaan dan pengungkapan Good Corporate Governance khususnya pada kedua Bank Umum Syariah yaitu BNI Syariah dan BRISyariah maka pelaksanaan Good Corporate Governance kedepannya harus berjalan lebih efektif dan tentunya memiliki scorel rating GCG yang tinggi.

Untuk memenuhi harapan tersebut maka perusahaan-perusahaan di Indonesia wajib melakukan:

23 Suprayitno G. Dan Susanty Aries, 2005, dalam Hamdani, Good Corporate Governance: Tinjauan Etika dalam Praktik Bisnis. Jakarta: Mitra Wacana Media, 2016, h-123. 
1. Pengelolaan perusahaan secara professional dan tidak memiliki hubungan afiliasi antara pemilik, pengawas, dan direktur perusahaan serta dewan komisaris.

2. Terciptanya hubungan yang simetris sehingga pemegang saham minoritas dapat berpartisipasi dalam pengambilan keputusan perusahaan.

3. Melakukan proteksi hukum bagi pemegang saham minoritas.

4. Meningkatkan score/rating keterbukaan.

Selain itu, pelaksanaan dan pengungkapan Good Corporate Governance harus sesuai sesuai dengan prinsip-prinsip Good Corporate Governance itu sendiri yaitu transparansi, akuntabilitas, responsibilitas, independensi serta kewajaran dan kesetaraan.

\section{DAFTAR PUSTAKA}

Edi Wibowo, 2010, Implementasi Good Corporate Governance di Indonesia. Jurnal ekonomi dan Kewirausahaan Vol. 10, No. 2, Oktober 2010.

Hamdani, 2016, Good Corporate Governance: Tinjauan Etika dalam Praktik Bisnis, Jakarta: Mitra Wacana Media.

http://www.tribunnews.com/nasional/2014/04/28/bank-century-punya-tiga-masalah-utama, diunduh Desember 2016

Kasri, Irma Aulia R. dan Niki Lukviarman. "Governance and Corporate Disclosure: A Studyin Bank Muamalat Indonesia and Bank Syariah Mandiri", dalam kumpulan Makalah Call for Paper yang lulus dalam seleksi Panitia International Seminar and Symposium on Implementation of Islamic Economics to Positive Economics in The World as Alternative of Conventional Economics System: Toward Development in The New Era, 2008. of The Holistic Economics, Unair, 1-2 Agustus 2008.

Komite Nasional Kebijakan Governance, 2006.

Komite Nasional Kebijakan Governance, Pedoman Umum Good Governance Bisnis Syariah, 2011.

N. Baydoun, and Willett R.., 1994,'Islamic Accounting Theory", Proceeding of AAANZ Annual Conference, Sydney, Australia.

Nurul Huda dan Mustafa Edwin Nasution, 2009, Current Issues Lembaga Keuangan Syariah, Jakarta: Kencana.

Pedoman Good Corporate Governance Perbankan Indonesia Dikeluarkan oleh: Komite Nasional Kebijakan Corporate Governance Januari 2004.

Sukrisno Agoes dan I Cenik Ardana. 2014. Etika Bisnis dan Profesi: Tantangan Membangun Manusia Seutuhnya. Jakarta: Salemba Empat. 